\title{
Bacterial exopolysaccharides from extreme marine habitat of Southern Ocean: Production and partial characterization
}

\section{Exopolisacáridos bacterianos obtenidos desde hábitat marino extremo del Océano Antártico: Producción y caracterización parcial}

\author{
Aparna Banerjee ${ }^{1,3}$, Pratibha Gupta², Vinod Nigam² \& Rajib Bandopadhyay ${ }^{1, *}$ \\ 'UGC-Center of Advanced study, Department of Botany, The University of Burdwan, Golapbag, Bardhaman-713104, West Bengal, India. \\ ${ }^{2}$ Department of Bio-Engineering, Birla Institute of Technology, Mesra, Rachi-835215, Jharkhand, India. \\ ${ }^{3}$ Centro de investigación de estudios avanzados del Maule (CIEAM), Vicerrectoría de Investigación y Postgrado, Universidad Católica del Maule, Talca, Chile. \\ *Email: rajibindia@gmail.com
}

\begin{abstract}
Deep marine microorganisms survive under extreme ecological settings and harsh environmental conditions of low temperature, high salinity, and high atmospheric pressure making it significant of scientific interest. Southern Ocean (SO) is one such example of deep marine ecosystem and the microorganisms inhabiting in such hostile environment may produce different bioactive secondary metabolites. SO (Indian Sector) is relatively less documented in terms of microbial composition and community dynamics. The present study involves isolation of exopolysaccharides (EPSs) from three potent SO (Indian Sector) bacteria, optimization of the EPS production and partial characterization of them. Three different EPSs show varying structural conformation, that is from porous to strong flakes mimicking polymeric structure with $\mathrm{C} / \mathrm{N}$ ratio ranging between 4 - 11. FTIR spectra have exhibited the presence of different active groups of carbohydrate moieties, water molecules and protein-associated amides. EPSs produced by marine microorganisms show high biotechnological promises such as drug carrier in pharmaceutical field, emulsifier and cryoprotectant in food-processing industry, detoxification of petrochemical oils and much more. The three bacterial isolates in this study showed potential of producing EPS biopolymer that can be further explored in terms of its proper biotechnological applications.
\end{abstract}

Keywords: Southern Ocean, marine bacteria, exopolysaccharides characterization

\section{RESUMEN}

Los microorganismos marinos de zonas profundas sobreviven en entornos ecológicos extremos y condiciones ambientales adversas de baja temperatura, alta salinidad y alta presión atmosférica, lo que los hace tener un interés científico particularmente significativo. El Océano Antártico, es uno de esos ejemplos de ecosistemas marino profundo, y los microorganismos que habitan en ese ambiente hostil pueden producir diferentes metabolitos secundarios bioactivos. El Océano Antártico (sector indio) está relativamente menos documentado en términos de composición microbiana y dinámica comunitaria. El presente estudio consiste en el aislamiento de los exopolisacáridos (EPS) de tres potentes bacterias del Océano Antártico (sector indio), la optimización de la producción de EPS y la caracterización parcial de los mismos. Tres EPS diferentes muestran una conformación estructural variable, es decir, de copos porosos a fuertes que imitan la estructura polimérica con una relación $\mathrm{C} / \mathrm{N}$ que oscila entre 4 y 11 . Los espectros FTIR han exhibido la presencia de diferentes grupos activos de macromoléculas de carbohidratos, 
moléculas de agua y amidas asociadas a proteínas. Los EPS producidos por microorganismos marinos muestran un alto potencial biotecnológico, como transportador de drogas en el campo farmacéutico, emulsionante y crioprotector, todos ellos en la industria de procesamiento de alimentos, desintoxicación de aceites petroquímicos y mucho más. Los tres aislamientos bacterianos de este estudio mostraron potencial de producción de biopolímeros de EPS que pueden ser explorados más a fondo en términos de sus aplicaciones biotecnológicas adecuadas.

Palabras clave: Océano Antárctico, bacterias marinas, caracterización de exopolisacáridos

\section{INTRODUCTION}

As the ocean is an important sink for the rapidly increasing anthropogenic $\mathrm{CO}_{2}$ concentration, flux of biogenic carbon to deep ocean water must be monitored on a regular basis (Delille 2004). The Southern Ocean (SO) contributes around $15 \%$ of the primary production of the oceans and thus play an important role in sequestering atmospheric $\mathrm{CO}_{2}$ through physical and biological processes (Huntley et al. 1991). Biodiversity of SO is least discovered element, making it a hub of unexplored biotic communities including Bacteria, Microalgae, Bryozoans, Diatom, Sponges, Coral, Tunicate or Fungi (Spolaore et al. 2006). Marine microorganisms are of particular interest because it survives under extreme ecological pressure and harsh environmental conditions; viz. low temperature, high salinity, high atmospheric pressure and exposure to radioactivity. Marine aggregates are also abundantly present in all the oceans around the world (Fowler \& Knauer 1986). Under hostile marine conditions, microorganisms produce several secondary metabolites including exopolysaccharides (EPSs) as a part of survival strategy (Nichols et al. 2005, Ewert \& Deming 2013). EPSs also provides a network that hold the bacterial structures together (Flemming \& Wingender 2001). EPSs such as dextran, xanthan, cellulose, succinoglycan are of high economic importance with good industrial values (Freitas et al. 2011, Banerjee \& Bandyopadhyay 2016, Halder et al. 2017). Dextran, specifically is the first commercialized bacterial EPS and is highly used in biomedical applications (Banerjee \& Bandopadhyay 2016).

Being one of the relatively unknown habitats of the earth with several polyextremophilic factors (De Broyer \& Danis 2011) and secondary metabolites or bioactive compounds produced by the $\mathrm{SO}$ microorganisms, it just might be a potent source of novel bioproduct with promising applications. EPSs also have an important role in Antarctic marine environment possibly acting as a ligand to the circling trace nutrients and cryo-protection for microbial growth at low temperature-high salinity environment (Nichols et al. 2005). Our present study is a first step to understand the biological potential of the SO bacteria and the role of bacterial EPSs in relatively less studied SO (Indian sector) environment. This study involves, isolation of EPSs from three potent SO (Indian Sector) bacteria, production optimization for maximum yield and partial characterization of the EPSs to get an idea about the structural composition of the constituting polysaccharides.

\section{MATERIALS AND METHODS}

\section{BACTERIAL IsOLATES}

Three different marine bacteria Zunongwangia profunda MB24 (KF019669), Marinobacter algicola MB-44 (KF019649) and Halomonas hydrothermalis MB-45 (KF019650) have been isolated from water sample taken from the Southern Ocean (Indian Sector) at a depth of $30 \mathrm{~m}, 500 \mathrm{~m}$ and 500 $\mathrm{m}$ respectively. Image of the study site has been adapted from Google Earth Pro. Ink. and is represented in Fig. 1. The methods of sampling and isolating the strains are described earlier (Gupta et al. 2015). Throughout the study, the strains are maintained at $20^{\circ} \mathrm{C}$ and routinely grown in Zobell Marine Broth (Himedia $®)$.

\section{Microscopic StUdY}

Morphological characterizations of the EPS producing marine isolates were done by fluorescence microscopy. Cultures were grown overnight on Zobell Marine Broth at $20{ }^{\circ} \mathrm{C}$ and cell pellet were formed by centrifugation at $500 \mathrm{rpm}$ for 5 min. They were then washed with $1 \times$ PBS buffer $(\mathrm{pH} 7.4)$ for several times and incubated at room temperature with zinc acetate for $30 \mathrm{~min}$. Excess zinc acetate was washed with 1x PBS buffer ( $\mathrm{pH}$ 7.4). Each sample was smeared over a clean grease free slide. Over this smear one drop $1 \mathrm{mM}$ zinc binding SALTM ligand (Kumari et al. 2015) was placed and covered with cover slip to observe under fluorescence microscope at $450 \mathrm{~nm}$ emission (Leica, DM 1000) by 100× objective lens. 


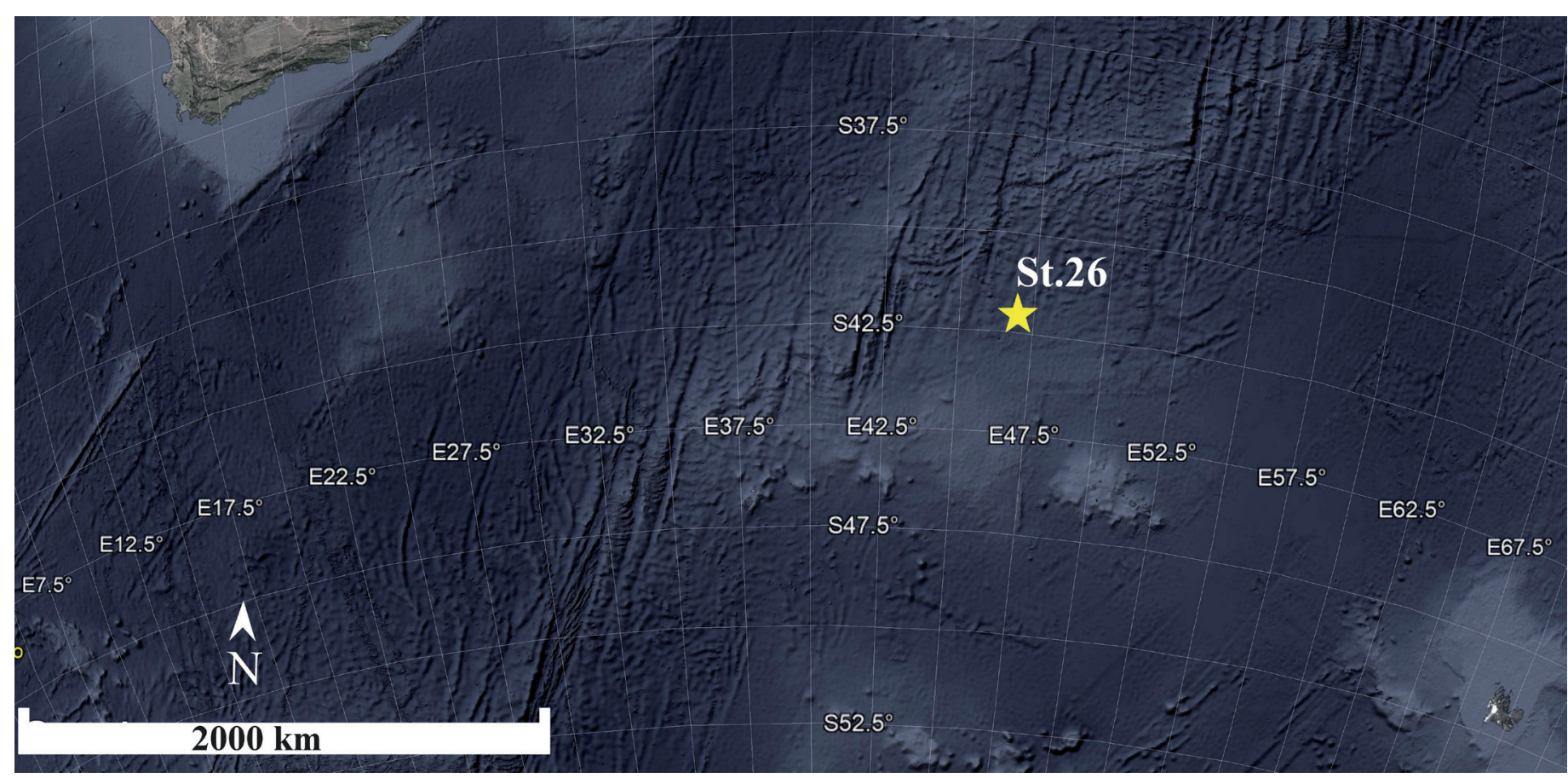

FIGURE 1. Study map representing the water sample collection point of station 26 in Southern Ocean (Indian sector). / El Mapa de estudio representa el punto de toma de muestras de agua de la estación 26, en el Océano Antártico (sector indio).

\section{Eps Production And Optimization}

Production and purification of the EPSs were done following the previously reported procedures (Banerjee et al. 2018, Sengupta et al. 2019). Zobell Marine Broth (Himedia ${ }^{\circledR}$ ) wasused for the growth of Z. profunda MB-24, M. algicola MB-44 and $\mathrm{H}$. hydrothermalis MB-45. The cultures were maintained at $20{ }^{\circ} \mathrm{C}$ with $150 \mathrm{rpm}$ shaking for 7 days. The production of EPS was done through centrifuging the culture medium in order to separate the cells from the supernatant at $15,000 \times g$ for $20 \mathrm{~min}$. The cell-free supernatant was collected for extraction of released EPSs. EPSs were extracted through a vacuum evaporating to half volume. To the solution, equal volumes of chilled ethanol was added, mixed and kept in at -4 ${ }^{\circ} \mathrm{C}$ for $24 \mathrm{~h}$ for precipitation of polysaccharides. Precipitates of formed EPSs were collected by centrifugation at 15,000 $\times \mathrm{g}$ and $20 \mathrm{~min}$, washed with same chilled solvent for few times. After that, it was centrifuged at $4{ }^{\circ} \mathrm{C}, 15,000 \times \mathrm{g}$ for $20 \mathrm{~min}$ in order to remove the proteins denatured by trichloroacetic acid. Finally, the purified EPS was obtained after dialysis followed by lyophilization. The dry weight of the EPS was calculated and stored for further analysis. Subsequently, the entire process was repeated with methanol, acetone and isopropanol as solvent to observe the change in EPS precipitation.

Media for the best EPS production was optimized by the addition of different carbon sources to the media (Glucose and Sucrose) followed by variation of the carbon source percentage supplemented with Zobell marine Broth as the standard ( $\mathrm{pH}$ 7.5). This media was further optimized by varying the nitrogen source content (Peptone and $\mathrm{NH}_{4} \mathrm{Cl}$ ). The inoculated flasks were incubated for 7 days at $20^{\circ} \mathrm{C}$ with $150 \mathrm{rpm}$ shaking followed by same EPS extraction protocol as mentioned above.

\section{Surface Morphology Characterization}

The surface morphology of isolated bacterial EPSs was analysed through scanning electron microscopy (SEM) (S530 Hitachi) study. The lyophilized EPSs were placed on an adhesive carbon tape. Gold coating (300 ̊̊) of the samples were performed using IB2 ion coater to make it conductive. The observations were made on surface morphological similarities of the different EPSs at different magnifications.

\section{Elemental Analysis}

The total nitrogen, carbon, hydrogen and sulfur content of the EPS samples determined using a CHNS analyzer (Vario EL III, M/s Elementar, Germany). For CHNS analysis, lyophilized and powdered EPS samples were weighed $(5-10 \mathrm{mg})$ and mixed with an oxidizer (vanadium pentoxide) in a tin capsule, which was then combusted in a reactor at $1000^{\circ} \mathrm{C}$. The EPSs were run along in order to find out the total content of CHNS present in samples with the $\mathrm{C} / \mathrm{N}$ ratios. 


\section{Infra-Red Spectroscopic Analysis}

Spectrums of bacterial EPSs were tested using a fourier transform infrared spectrophotometer (IR-Prestige 21, Shimadzu Corporation, Japan). The spectrums of EPSs were obtained by $\mathrm{KBr}$ pellet method where the EPSs were pressed into dry Potassium bromide $(\mathrm{KBr})$ at a sample: $\mathrm{KBr}$ ratio of 1:90 to form a disc of around $3 \mathrm{~nm}$ diameter. These spectra were further analyzed for interpretation of the major functional groups present in the EPSs after subjecting to FTIR- spectra measurement in the frequency range of 400 and $4000 \mathrm{~cm}^{-1}$.

\section{RESULTS}

\section{Microscopic StUdy}

Fluorescence microscopic observation revealed that the EPSs producing marine isolates were small branched rod or coccoid shaped bacteria (Figs. 2A, 2B and $2 \mathrm{C}$ ). All the three marine isolates; viz. Z. profunda MB-24, M. algicola MB-44 and $H$. hydrothermalis $\mathrm{MB}-45$ have shown one common unique feature of closely attached clumps of bacterial cells which are probably an indication of EPS production for survival at extreme temperature by staying together under the sheath of EPS.

\section{Eps Production And Optimization}

Highest EPS production was observed by $\mathrm{H}$. hydrothermalis MB-45, which was $5.26 \mathrm{~g} / \mathrm{l}$ with $1 \%$ glucose and sucrose combination added to the media as carbon source and isopropanol as solvent for precipitation. While both $Z$. profunda MB-24 and M. algicola MB-44 produced EPSs maximum $2.4 \mathrm{~g} / \mathrm{l}$ and $4.4 \mathrm{~g} / \mathrm{l}$ respectively when precipitated using ethanol as a solvent and $2 \%$ Glucose as added carbon source in production medium. Methanol was comparatively proved to be a poor solvent for EPS precipitation, (Figs. 3A and $3 \mathrm{~B}$ ) for all the three different Southern Ocean isolates.
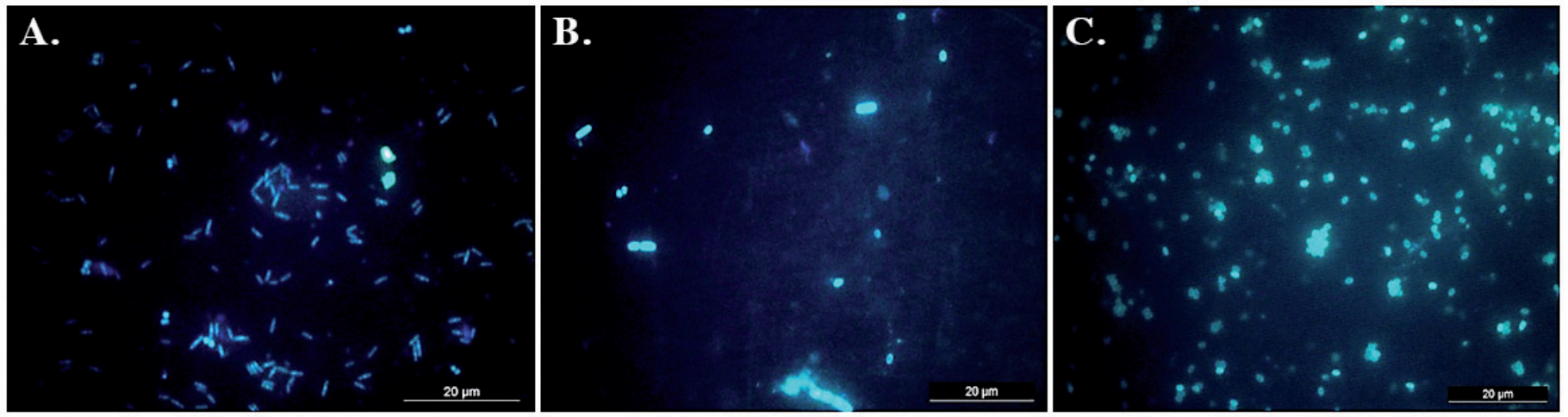

FIGURE 2. Fluorescence microscopy images of the EPS producing Southern Ocean bacteria; where A. Zunongwangia profunda MB-24, B. Marinobacter algicola MB-44 and C. Halomonas hydrothermalis MB-45 respectively. / Imágenes de microscopía de fluorescencia de EPS producido por bacterias del Océano Antártico; donde A. Zunongwangia profunda MB-24, B. Marinobacter algicola MB-44 y C. Halomonas hydrothermalis $\mathrm{MB}-45$ respectivamente.
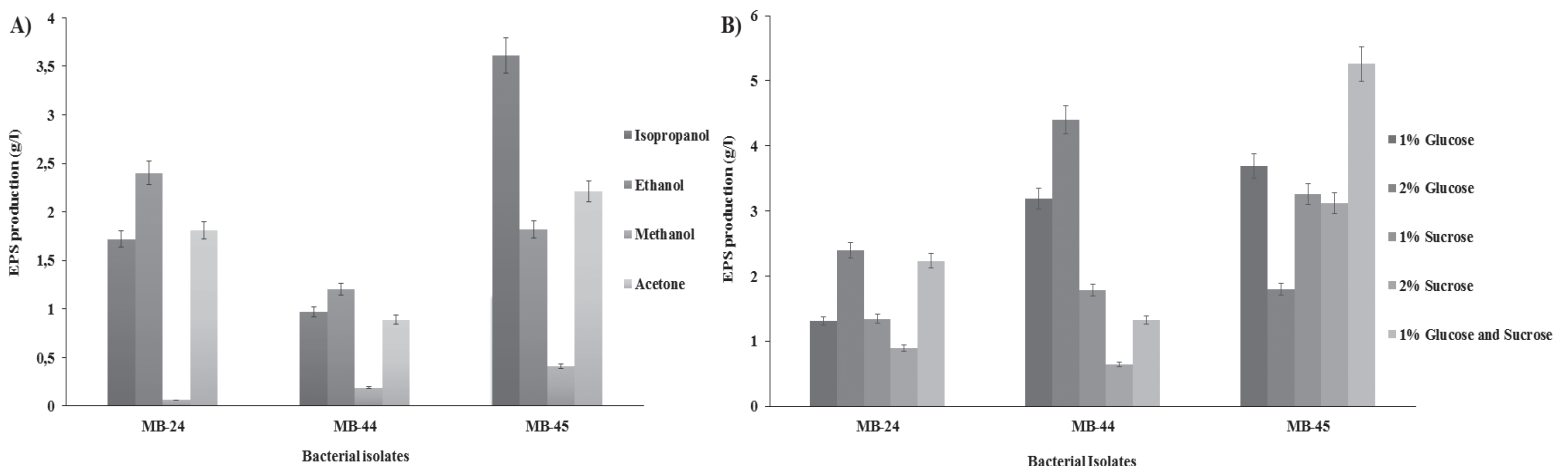

FIGURE 3. Production and optimization of EPS by the Southern Ocean bacteria; where A. Optimization of EPS production by solvent variation and B. Optimization of EPS production by varying the carbon source using the best solvent for EPS precipitation. The error bars represent $95 \%$ confidence interval for both cases. / Producción y optimización de EPS por bacterias del Océano Antártico; donde A. Optimización de la producción de EPS mediante variación del solvente y B. Optimización de la producción de EPS mediante la variación de la fuente de carbono usando el mejor solvente para la precipitación de EPS. Las barras de error representan un intervalo de confianza del $95 \%$ para ambos casos. 
Surface Morphology Characterization

The lyophilized EPS were found to be a creamish powder, which was water soluble in nature. Surface morphology of the EPSs characterized by SEM, revealed its structural similarity with earlier reported EPSs of Southern Ocean (Indian Sector)- origin marine resources (Sengupta et al. 2019). While Z. profunda MB-24 showed porous structure (Figs. 4A and 4B); M. algicola MB-44 (Figs. 4C and 4D) and H. hydrothermalis MB45 (Figs. 4E and 4F) exhibited compact flakes-like structural EPS units.

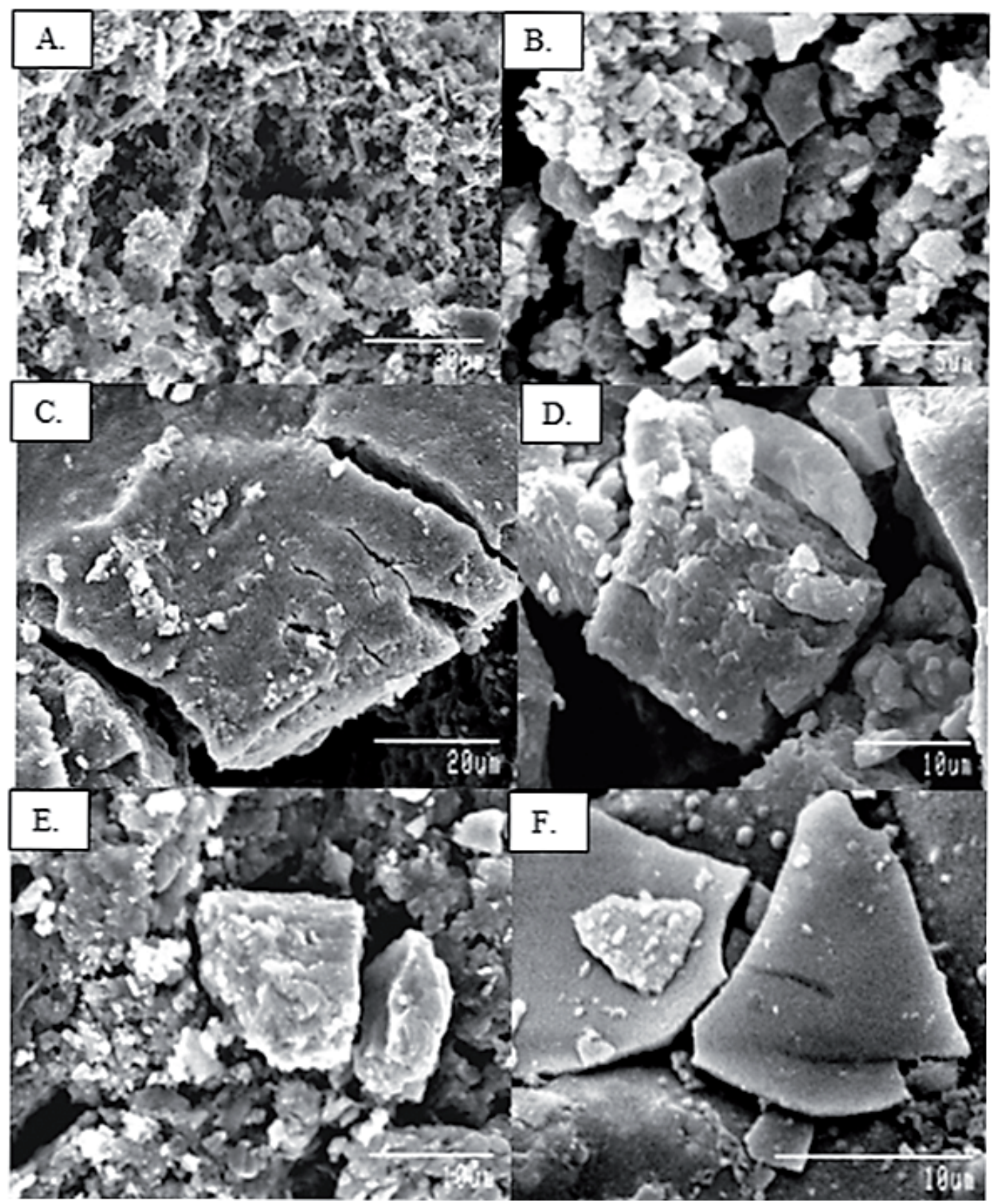

FIGURE 4. Surface morphology characteristics of the EPSs; where A. and B. Zunongwangia profunda MB-24 at 1500× and 6000×, C. and D. Marinobacter algicola MB-44 at 1500x and 3000x; and E. and F. Halomonas hydrothermalis MB-45 at 3000x and 5000x magnifications respectively. / Características morfológicas superficiales de los EPSs; donde A. y B. Zunongwangia profunda MB-24 a 1500× y 6000×, C. y D. Marinobacter algicola MB-44 a 1500× y 3000x; E. y F. Halomonas hydrothermalis MB-45 a 3000× y 5000× de magnificación respectivamente. 


\section{Elemental Analysis}

Elemental Analysis of EPSs revealed a $\mathrm{C} / \mathrm{N}$ ratio range of fresh organic matter. Percentage of sulphur in trace amount also proved the isolated EPSs to be in pure polysaccharide form. Normally, polysaccharide-rich samples showed only small amounts of nitrogen $\sim 1 \%$ (Synytsya et al. 2009). However, sometimes aminated polysaccharides contains
5\% nitrogen too (Du et al. 2017). Thus, from the results of elemental analysis EPS produced by Z. profunda MB24 was polysaccharide rich; while $M$. algicola MB-44 and $H$. hydrothermalis MB-45 produced EPSs were probably aminated EPSs (Table 1). C/N ratio of $Z$. profunda MB-24, $M$. algicola MB-44 and $\mathrm{H}$. hydrothermalis MB-45 are $11.59,8.921$ and 4.896 respectively.

$T_{A B L E}$ 1. CHNS percentage and $\mathrm{C} / \mathrm{N}$ ratio present in the EPSs produced by the Southern Ocean bacteria. / Porcentaje de CHNS y relación $\mathrm{C} / \mathrm{N}$ presente en los EPS producidos por bacterias del Océano Antártico.

\begin{tabular}{lccccc}
\hline Sample & C/N ratio & \% of Carbon & \% of Hydrogen & \% of Nitrogen & \% of Sulfur \\
\hline Zunongwangia profunda MB-24 & 11.590 & 19.690 & 4.993 & 1.698 & 1.351 \\
Marinobacter algicola MB-44 & 8.921 & 26.720 & 6.243 & 2.995 & 0.771 \\
Halomonas hydrothermalis MB-45 & 4.896 & 28.940 & 6.292 & 5.911 & 0.698 \\
\hline
\end{tabular}
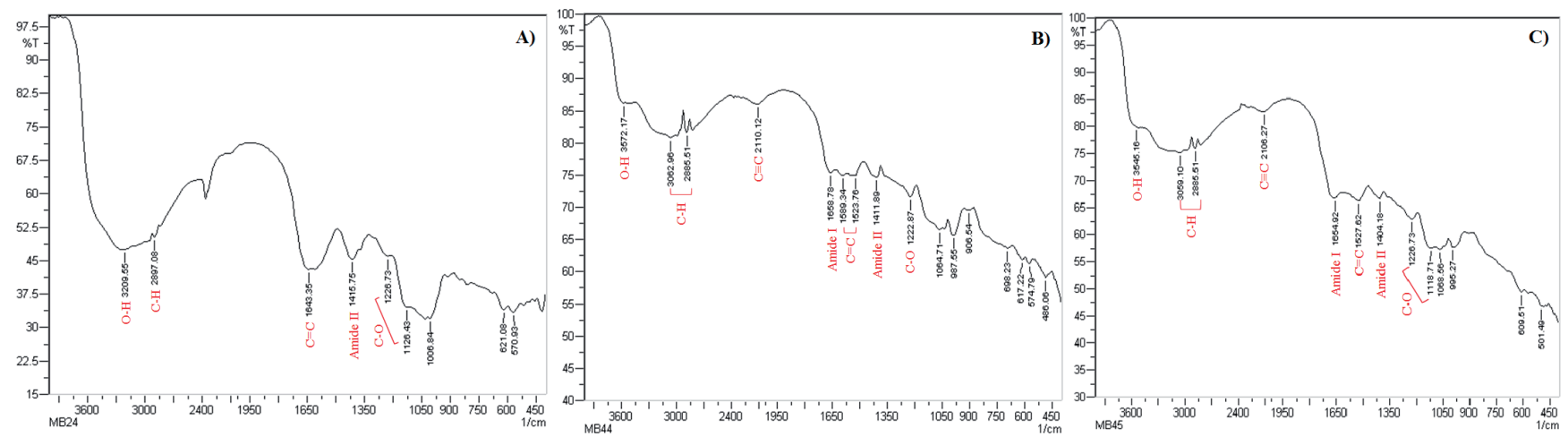

FIGURE 5. FTIR spectra of the EPSs produced by the Southern Ocean bacteria; where A. Zunongwangia profunda MB-24, B. Marinobacter algicola MB-44 and C. Halomonas hydrothermalis MB-45 respectively. / Espectros FTIR de los EPS producidos por bacterias del Océano Antártico; donde A. Zunongwangia profunda MB-24, B. Marinobacter algicola MB-44 y C. Halomonas hydrothermalis MB-45 respectivamente.

\section{Infra-Red Spectroscopic Analysis}

Infrared spectra of the EPSs extracted from all three marine isolates showed common specific absorbance of broad $\mathrm{O}-\mathrm{H}$ stretching at $3200-3600 \mathrm{~cm}^{-1}$, strong $\mathrm{C}-\mathrm{H}$ stretching at $2850-3000 \mathrm{~cm}^{-1}$. variable $\mathrm{C}=\mathrm{C}$ stretching at $\sim 1640 \mathrm{~cm}^{-1}$, and strong C-O stretching at $\sim 1200 \mathrm{~cm}^{-1}$. Besides this, $\mathrm{C}=\mathrm{O}$ of amide I at $\sim 1680 \mathrm{~cm}^{-1}$ indicated the presence of proteinassociated amides in the EPSs produced by M. algicola MB44 and H. hydrothermalis MB-45 (Hellwig et al. 1998, Cao et al. 2011, Demirbaş et al. 2013). Presence of Amide II (N-H bending vibration and $\mathrm{C}-\mathrm{N}$ stretching vibration) were also observed with the peaks $\sim 1400 \mathrm{~cm}^{-1}$. Overall, the results indicate the presence of water molecule of polysaccharide compound, alkane groups, alkenes, methylene group of alkanes respectively (Figs. 5A, 5B and 5C). M. algicola
MB-44 produced EPS is relatively complex in branching due to the presence of characteristic skeletal breathing of polysaccharide macromolecules (Fan et al. 2012).

\section{DISCUSSION}

Microbial EPSs are ubiquitous in extreme marine environment where they are essential for bacterial survival. EPS is biopolymeric in nature and helps in biofilm formation ( $\mathrm{Di}$ Donato et al. 2016). These biofilms provide a protection sheath to microorganisms by formation of complex association among cells and entrapment of nutrients ( $\mathrm{Di}$ Donato et al. 2016). Thus, they assist the microbial communities to tolerate extreme temperature, salinity and allow nutrient availability 
by creating a border between bacterial cells and its immediate environment (Kumar et al. 2018). Several EPSs produced by marine microorganisms show biotechnological promises (Dionisi et al. 2012). Marine prokaryotes are reported to produces biopolymers novel biomaterial properties and industrial suitability (Weiner 1997). Examining their structure and physio-chemical characteristics as focused in this present study is just a primary draft step to a large field of possibilities. Further, it is possible to gain insight into their commercial applications in pharmaceutical industry and food-processing fields or bioremediation of petrochemical spillage (Weiner 1997, Di Donato et al. 2016). All the three SO (Indian Sector) origin bacteria reported in this study were found to be good producers of EPSs but $\mathrm{H}$. hydrothermalis MB-45 produced maximum EPS of $5.26 \mathrm{~g} / \mathrm{l}$. The $\mathrm{C} / \mathrm{N}$ ratio of the EPSs were in the range of $4-11 . \mathrm{C} / \mathrm{N}$ ratios in the range of 4-10 were usually reported to be from marine sources (Gray \& Biddlestone 1973). In a previous report by Sengupta et al. (2019), a Pseudoalteromonas isolate of SO (Indian Sector) origin showed similar $\mathrm{C} / \mathrm{N}$ ratio of the EPS. This supports the elemental analyses of this present study. Surface morphology of the EPS produced by Z. profunda MB24 showed structural identities to earlier reported EPS from SO (Indian sector) origin Pseudoalteromonas sp. in terms of smooth and distinct porous regions in the EPS (Sengupta et al. 2019). Porous EPS produced by Z. profunda MB-24 was probably polysaccharide macromolecules joined each other with a-glycosidic bonds and were polysacchariderich. Compact EPSs produced by M. algicola MB-44 and $H$. hydrothermalis MB-45 were found to be amine-substituted. While compact structure of EPS indicated its potential to be used as viscosifier, thickener or stabilizing agent for use in food industry because of plasticized film like property (Sajna et al. 2013); porous EPS structure were proven to be a good candidate for heavy metal biosorption (Qiang et al. 2013), while also having the capillary force to hold more water (Rani et al. 2017). The fibrous pores of bacterial EPSs were already proved to help bacterial cells to stay attached to each other due to high affinity interactions (Rani et al. 2017). Thus the psychrohalophilic bacterial isolates from $\mathrm{SO}$ explored in this study may have produced EPSs as an extracellular response to the environmental constraints. Bacterial EPS production as a response to cold, sea environment was explained earlier by Ewert \& Deming (2013). Infra-red spectra of the three EPSs showed distinctive functional groups normally present in polysaccharide macromolecules. M. algicola MB-44 produced EPS was particularly interesting as it shows highly complex aminated polysaccharide branching along with characteristic skeletal breathing (Fan et al. 2012) of polysaccharides. Presence of major amount of proteins in EPS produced by SO bacteria is already earlier reported by Nichols et al. (2005). The frequency and types of functional groups present in a EPS macromolecule affect the tertiary structure and overall physicochemical characteristics of the biopolymer in response to the surrounding environment (Decho \& Lopez 1993). SO origin bacterial EPSs were reported to have applications in food processing industry as thickening agent, anti-coagulant property, anti-HIV activity, biodetoxification for waste water treatment (Nichols et al. 2005) and UV-protection capacity (Núñez-Pons et al. 2018). Considering that the microbial diversity of SO ecosystem is less documented and both the compact or porous nature of the EPS with substantial functional groups present in the biopolymer as documented in this study, it is reasonable to hypothesize that the isolation and identification of new marine microorganisms and identifying their different secondary metabolites; viz. EPS production will provide a deep insight into the wide opportunities for new industrial applications in future.

\section{ACKNOWLEDGEMENT}

Authors are thankful to UGC-Center of Advanced Study, Department of Botany, The University of Burdwan for pursuing research activities. We are thankful for the Expedition support to MoES, New Delhi and NCAOR, Goa (No. MoES/NCAOR/ SOS/1/2007-PC-I; dated Jan 04, 2011), and BIT Mesra, Ranchi. Aparna Banerjee is thankful to UGC for the financial assistance of JRF (State Funded) [Fc (Sc.) /RS/SF/BOT./2014$15 / 103(3)]$.

\section{REFERENCES}

Banerjee, A., Bandopadhyay, R. 2016. Use of dextran nanoparticle: A paradigm shift in bacterial exopolysaccharide based biomedical applications. International Journal of Biological Macromolecules 87:295-301.

Banerjee, A., Rudra, S.G., Mazumder, K., Nigam, V., Bandopadhyay, R. 2018. Structural and functional properties of exopolysaccharide excreted by a novel Bacillus anthracis (Strain PFAB2) of hot spring origin. Indian journal of microbiology 58(1):39-50.

Cao, Y., Wei, X., Cai, P., Huang, Q., Rong, X., Liang, W. 2011. Preferential adsorption of extracellular polymeric substances from bacteria on clay minerals and iron oxide. Colloids and Surfaces B: Biointerfaces 83(1):122-127.

De Broyer, C., Danis, B. 2011. How many species in the Southern Ocean? Towards a dynamic inventory of the Antarctic marine species. Deep sea research Part II: Topical studies 
in oceanography 58(1-2):5-17.

Decho, A.W., Lopez, G.R. 1993. Exopolymer microenvironments of microbial flora: multiple and interactive effects on trophic relationships. Limnology and oceanography 38(8):1633-1645.

Delille, D. 2004. Abundance and function of bacteria in the Southern Ocean. Cellular and molecular biology 50(5):543-551.

Demirbaş, Ö., Alkan, M., Demirbaş, A. 2013. Surface properties of catalase and casein on kaolinite and design of experiments. Microporous and Mesoporous Materials 172:151-160.

Di Donato, P., Poli, A., Taurisano, V., Abbamondi, G.R., Nicolaus, B, Tommonaro, G. 2016. Recent advances in the study of marine microbial biofilm: from the involvement of quorum sensing in its production up to biotechnological application of the polysaccharide fractions. Journal of Marine Science and Engineering 4(2):34.

Dionisi, H.M., Lozada, M., Olivera, N.L. 2012. Bioprospection of marine microorganisms: biotechnological applications and methods. Revista argentina de microbiología 44(1):49-60.

Du, B., Yang, Y., Bian, Z., Xu, B. 2017. Characterization and antiinflammatory potential of an exopolysaccharide from submerged mycelial culture of Schizophyllum commune. Frontiers in pharmacology 8:252.

Ewert, M., Deming, J. 2013. Sea ice microorganisms: Environmental constraints and extracellular responses. Biology 2(2):603-628.

Fan, M., Dai, D., Huang, B. 2012. Fourier transform infrared spectroscopy for natural fibres. In: Fourier transformmaterials analysis. IntechOpen.

Flemming, H.C., Wingender, J. 2001. Relevance of microbial extracellular polymeric substances (EPSs)-Part I: Structural and ecological aspects. Water science and technology 43(6):1-8.

Fowler, S.W., Knauer, G.A. 1986. Role of large particles in the transport of elements and organic compounds through the oceanic water column. Progress in Oceanography 16(3):147-194.

Freitas, F., Alves, V.D., Reis, M.A. 2011. Advances in bacterial exopolysaccharides: from production to biotechnological applications. Trends in biotechnology 29(8):388-398.

Gray, K.R., Biddlestone, A.J., 1973. Composting-process parameters. The Chemical Engineer 2:71-76.

Gupta, P., Balaji, R., Parani, M., Chandra, T.S., Shukla, P., Kumar, A., Bandopadhyay, R. 2015. Phylogenetic analysis and biological characteristic tests of marine bacteria isolated from Southern Ocean (Indian sector) water. Acta Oceanologica Sinica 34:73-82.

Halder, U., Banerjee, A., Bandopadhyay, R., 2017. Structural and functional properties, biosynthesis, and patenting trends of Bacterial succinoglycan: a review. Indian journal of microbiology 57(3):278-284.

Hellwig, P., Behr, J., Ostermeier, C., Richter, O.M., Pfitzner, U., Odenwald, A., Ludwig, B., Michel, H., Mäntele, W. 1998. Involvement of glutamic acid 278 in the redox reaction of the cytochrome c oxidase from Paracoccus denitrificans investigated by FTIR spectroscopy. Biochemistry 37(20):7390-7399.

Huntley, M.E., Lopez, M.D., Karl, D.M. 1991. Top predators in the Southern Ocean: a major leak in the biological carbon pump. Science 253(5015):64-66.

Kumar, D., Kastanek, P., Adhikary, S.P. 2018. Exopolysaccharides from cyanobacteria and microalgae and their commercial application. Current Science 115(2):234-241.

Kumari, B., Lohar, S., Ghosh, M., Ta, S., Sengupta, A., Banerjee, P.P., Chattopadhyay, A., Das, D. 2016. Structurally Characterized $\mathrm{Zn}^{2+}$ Selective Ratiometric Fluorescence Probe in 100\% Water for HeLa Cell Imaging: Experimental and Computational Studies. Journal of fluorescence 26:87-103.

Nichols, C.M., Guezennec, J., Bowman, J.P. 2005. Bacterial exopolysaccharides from extreme marine environments with special consideration of the southern ocean, sea ice, and deep-sea hydrothermal vents: a review. Marine biotechnology 7(4):253-271.

Nichols, C.M., Lardière, S.G., Bowman, J.P., Nichols, P.D., Gibson, J.A., Guézennec, J. 2005. Chemical characterization of exopolysaccharides from Antarctic marine bacteria. Microbial ecology 49(4):578-589.

Núñez-Pons, L., Avila, C., Romano, G., Verde, C., Giordano, D. 2018 UV-protective compounds in marine organisms from the Southern Ocean. Marine drugs 16(9):336.

Qiang, L., Yumei, L., Sheng, H., Yingzi, L., Dongxue, S., Dake, H., Jiajia, W., Yanhong, Q., Yuxia, Z. 2013. Optimization of fermentation conditions and properties of an exopolysaccharide from Klebsiella sp. H-207 and application in adsorption of hexavalent chromium. PloS one 8(1):e53542.

Rani, R.P., Anandharaj, M., Sabhapathy, P., Ravindran, A.D. 2017. Physiochemical and biological characterization of novel exopolysaccharide produced by Bacillus tequilensis FR9 isolated from chicken. International journal of biological macromolecules 96:1-10.

Sajna, K.V., Sukumaran, R.K., Gottumukkala, L.D., Jayamurthy, H., Dhar, K.S., Pandey, A. 2013. Studies on structural and physical characteristics of a novel exopolysaccharide from Pseudozyma sp. NII 08165. International Journal of Biological Macromolecules 59:84-89.

Sengupta, S., Banerjee, A., Halder, U., Gupta, P., Banerjee, C., 
Bandopadhyay, R. 2019. Comparative Study on Structure of Exopolysaccharide and Capsular Polysaccharide Produced by Southern Ocean Origin Pseudoalteromonas sp. MB-16. Proceedings of the National Academy of Sciences, India Section B: Biological Sciences 89(1):283-290.

Spolaore, P., Cassan, C.J., Duran, E., Isambert, A. 2006. Commercial application of microalgae. Journal of Bioscience and Bioengineering 101:87-96.
Synytsya, A., Míčková, K., Synytsya, A., Jablonský, I., Spěváček, J., Erban, V., Kováŕíková, E., Čopíková, J. 2009. Glucans from fruit bodies of cultivated mushrooms Pleurotus ostreatus and Pleurotus eryngii: Structure and potential prebiotic activity. Carbohydrate polymers 76(4):548-556.

Weiner, R.M. 1997. Biopolymers from marine prokaryotes. Trends in biotechnology 15(10):390-394.

Received: 02.05.2019

Accepted: 06.11.2019 